\title{
DEVELOPMENT OF STUDENTS' LEARNING-KNOWING COMPETENCE IN VOCATIONAL EDUCATION
}

\section{Zokir Toshtemirovich Rakhimov}

Doctor Of Philosophy In Pedagogy, Professor, Chair “Social Sciences”, Karshi Engineering-Economics Institute, Uzbekistan

\section{ABSTRACT}

This article discusses the rapid inflow and large-scale flow of information into society today, the rapid receipt of information, its analysis, processing, theoretical generalization, summarization and delivery to the student, the achievement of quality and efficiency in the educational process, the acquisition of individual knowledge and skills by the student to enhance the knowledge and experience required for in-depth study, the acquisition of integrative knowledge and actions in each independent direction, the requirements for the level of professional training of students, the appropriate use of knowledge, skills and methods, the student's acquisition of knowledge, skills and abilities necessary for the implementation of professional activities of personal and social significance and the ability to apply them in professional activities indicates the competence of the student, and the educational competence of the student is a set of independent thinking competencies, consisting of elements of logical, methodological and social activities related to the specific objects under study, including knowledge and skills in goal setting, activity planning, content analysis, reflection, personal evaluation of activities, competence and learning. The full essence of such concepts as competence, pedagogical conditions, necessary factors and important aspects of the development of students' learning competence in the process of higher education are explained in the article.

KEYWORDS:- Student, education, process, quality, result, competence, ability, knowledge, skill, qualification, necessity, creativity, profession, motive, formation, development.

\section{INTRODUCTION}

In these days, in the training of future professionals in the educational process, one of the important directions is the maximum satisfaction of the educational needs of the individual and society, the optimization of vocational training. The main feature of continuing professional training is the adherence to the principle of continuity, reliance on tradition in achieving educational goals.

Important work is being done to reform the form and content of the education system, improve its legal framework, strengthen the material and technical base, increase the content, form and effectiveness of education[6]. Because the education system has a place in the world, building a prestigious society, ensuring the democratic development of our country and the formation of civil society, its democratization and liberalization, raising the level of political, legal, spiritual, moral, social consciousness and worldview of citizens is considered the foundation of the formation. That is why today one of the directions in the education system the innovative activity of educational institutions - is identified as a key factor. It is important for every future specialist to understand the need to reform the education system and its importance 
in practice to join the innovative processes of educational institutions, and to see themselves in the innovative space where there is an opportunity to create and, most importantly, to learn.

Analysis of the activities of teachers of vocational education in higher education institutions shows that they need to develop professional competence in their subject and the education of a harmoniously developed generation and the ability to apply them consistently in future professional activities.

In modern society, the level of development of a country is determined not only by its technical condition, but also by the professional competence of specialists trained in higher education institutions[3].

MAIN PART. Modernization of the education system, changes in the system of vocational education make it necessary to develop the professional competence of the staff of the educational institution. At present, the state educational standards of higher professional education are being introduced, and innovations are being widely introduced in the content and technology of education aimed at improving the quality of training of future teachers of vocational education.

The English concept of «competence» literally means «ability». The content means «effective use of theoretical knowledge in practice, the ability to demonstrate a high level of professionalism, skill and talent» [8].

The concept of «competence» means having a plan of action in unusual situations, how to behave in unexpected situations, to communicate, to behave in a new way in dealing with competitors, to perform ambiguous tasks, to use conflicting information, to evolve and complex processes [1].

The analysis shows that in the educational process, many scientists have conducted research on the problems of developing students' learning competencies and improving their professional training. In particular, according to N.A.Muslimov and K.Abdullayeva, competence is the level of independent and creative application of the set of theoretical knowledge, skills and abilities in practice, which is formed in the student's internship and postgraduate activities [4].

As the well-known pedagogical scientist A.R.Khodjaboyev [10] highlited, “.... tools, units, equipment, machines and mechanisms used in the educational process of higher education institutions, schools and vocational schools are not only means of production, but primarily educational tools, which allow students to develop and strengthen their professional skills and abilities that they will have".

Edward Friedrich Zeer evaluates competence as one of the main components of the structure of professional activity, as well as the fact that the person has a focus, professionally important qualities and psychophysiological characteristics [2].

In the researches of Tatyana M. Sorokina, the professional competence of the teacher is interpreted as a unit of theoretical and practical training for the implementation of pedagogical activities. His teaching competence is one of the stages of professionalism that is the basis of a teacher's pedagogical activity [9].

A.V.Khutorsky [11] explains the difference between the concepts of «competence» and «competency» between the concepts of «synonym used». Competence is a set of interrelated characteristics of an individual (knowledge, skills, methods of activity), defined for specific topics and processes and necessary for the qualitatively effective production of them.

A distinction must be made between competence 
and skill. Ability is a characteristic feature that can be learned from the observations of action, competence - actions, skills in a particular situation. Thus, skills are manifested in practice as competencies. Competence is something that is a skill, something that enhances action. Competence is formed as a result of conscious activity. The concept of competence is defined as the ability to apply knowledge, skills, personal qualities and practical experience to succeed in a particular field. The main types and content of competence [12] are given below:

Value-content competence is the competence of the student in the worldview associated with valuable ideas, his ability to see and understand the world around us, to be aware of their role and goals, to choose purposeful and meaningful attitudes to their actions and behavior, to make decisions.

General cultural competence is the range of issues that a student should be well aware of, knowledge and experience in their work. These are the characteristics of national and universal culture, the spiritual and moral foundations of human life and humanity, the role of science and religion in human life, their impact on the world, competencies in everyday and cultural recreation, for example, effective ways of organizing leisure.

Learning-cognitive competence is a set of a number of competencies of the elements of logical, methodical, general educational activity of the student in the field of independent cognitive activity, including interrelated with real known things. This includes goal setting, planning, analysis, reflection, and selfassessment in learning activities. Within these competencies, appropriate functional literacy requirements are identified: distinguishing evidence from suspicion, having measurement skills, using probability, statistics, and other cognitive methods.
Information competence is the ability to independently search, analyze and use the necessary information using real objects (television, tape recorder, telephone, fax, computer, printer, modem, photocopier) and information technology (audio and video recordings, e-mail, media, Internet) skills in selecting, organizing, converting, storing, and transmitting them are formed.

Communicative competence includes knowledge of required languages, ways of communicating with others, distant people and events, teamwork skills, possession of various social roles in the team. Students can introduce themselves, write letters, fill out questionnaires, forms, ask questions, have discussions, and so on.

Socio-labour competence is in the field of social and labour (consumer, buyer, customer, producer), civic activities (citizen, observer, voter, representative), family relations and responsibilities, economics and law, professional self-determination means to have knowledge and experience in designation. This competence includes, for example, the analysis of the situation in the labour market, acting in accordance with personal and public interests, and having ethics in labour and civil relations. Students have the social activism and functional literacy skills that are minimal necessary for life in modern society.

Personal self-improvement competence focuses on learning ways to develop physically, mentally, and intellectually, manage emotional feelings, and support oneself. The real object is where the student himself emerges. He constantly manages his activities with his own interests and abilities, which are manifested in the development of personal knowledge, psychological literacy, culture of thinking and behavior, which are necessary for modern man. These competencies include the rules of personal hygiene, personal medical care, sexual literacy, internal 
environmental culture. It also includes a number of features related to the basics of life activity safety.

The main components of competence are as following:

$>$ Knowledge, not just information, but fastchanging, dynamic, changeable, information that you need to find, that you don't need, that you turn into your own experience.

$>$ The ability to apply this knowledge in a given situation to understand how to acquire this knowledge.

$>$ Adequate (appropriate) assessment themselves, their world, their place in the world, their specific knowledge, the necessity or uselessness for their activities, as well as the method of obtaining or using them.

$>$ Competence develops on the basis of mobility of knowledge, flexibility of method and critical thinking. Competence development in the learning process is based on:

$>$ Achieving a goal and organize one's own success, to explain one's goal;

$>$ Planning, analysis, reflection, organization of self-assessment of educational activities;

$>$ Asking questions about the evidence being examined, searching for the causes of events, understanding or pointing out misunderstandings in solving the problem being studied;

$>$ Defining cognitive tasks and making assumptions; selection of observation or experimental conditions; select the necessary tools and equipment, have measurement skills, work with instructions;

$>$ Applying their knowledge of analytical and statistical methods;
$>$ Describing the results, formulate conclusions;

$>$ Oral and written presentation of research results using computer tools and technologies (text and graphic editors, presentations);

$>$ Having the experience of perceiving the image of the world.

Educational competencies play an important role in the formation of highly qualified professionals, as they provide the professional movement of graduates of educational institutions who can change the scope of their specialization and professional activity if necessary. Thus, learning competencies are a factor of social competitiveness. The formation and development of learning activities takes place during the transition from external management to self-management and self-organization.

The competency-based approach is one of the new conceptual guidelines for developing educational content [5].

According to modern educators, the acquisition of vital competencies allows a person to travel in modern society, forming a person's ability to respond quickly to the demands of time [7].

The term "competency approach" refers to the core of the learning process for the formation and development of a person's main (key, core) and subject competencies. The result of this process is the formation of a person's general competence, a set of basic competencies, an integrative description of the person. Having such a character should be formed in the educational process and have knowledge, skills, relationship experience, work experience.

A competency-based approach to education is related to current approaches to personcentered learning because it can be implemented and tested in a specific demand process that is 
individual to the student and performs a specific set of actions.

Competence is a requirement for the educational training of a specialist, which is necessary for effective work in a particular field.

Competency is the acquisition by a person of competencies related to the subject of activity.

Based on the above, we have given our working definition of competency. Competency is the acquisition by an individual of interrelated characteristics of an individual, including a personal relationship and a subject of activity.

Learning-cognitive competence ensures the effectiveness of the development of professional and special competencies, which allows its development to be considered a priority of modern education.

Learning-cognitive competence takes precedence in a certain part of an individual's competencies, ensuring that a person acquires a comprehensive and diverse cultural world.

In our opinion, learning-cognitive competence is the main competence aimed at expanding knowledge, mastering the methods of cognitive activity, the formation of certain knowledge and skills in educational activities, the development of creative thinking and independence in learning activities.

Therefore, we have defined the learningcognitive competence of future vocational education teachers as the acquisition of specific competencies that form the theoretical knowledge, practical skills and competencies necessary for them in preparation for independent learning activities.

We believe that the following skills should be used as criteria for improving the learningcognitive competence:

The ability to set goals and organize their capabilities, to explain their purpose;
$>$ Formulating cognitive tasks and make assumptions;

$>$ Analysis of one's own learning activities;

$>$ Acquiring knowledge independently;

$>$ Implementation of reflection (reflection) in their educational activities;

$>$ Self-assessment in their learning activities;

$>$ Present the results of their research orally and in written form.

\section{Results AND DISCUSSIONS}

The following main factors are based on the professional and methodological training of future teachers of higher education in higher education institutions, which are:

$>$ Professional and methodological training of future teachers of vocational education;

$>$ Professional and technological approach to the creative formation and development of the personality of the future teacher of vocational education in the context of modern information technology on the basis of systematic, pedagogical integration;

$>$ Equipping future vocational education teachers with methodological knowledge, as well as methodological knowledge;

$>$ Expanding and deepening the structure and content of the methodological system of training future teachers of vocational education.

Among the important pedagogical conditions that contribute to the professional formation of a future engineer-pedagogue are the following:

1. Material and technical conditions (educational buildings, classrooms, training workshops, practical-laboratory equipment), information technology (radio, television, computer, copiers, 
laboratory equipment, tape recorders (audio, video), simulators, video projector , availability of a set of technical means, etc.).

2. Educational-methodical normative documents (state educational standard, standard curricula, working curricula, model and working curricula, textbooks, manuals, methodical recommendations, additional special literature, visual aids, lesson plans, projects, et cetera).

3. Potential of scientific and pedagogical staff (professors, associate professors, teachers, qualified teachers, supervisors and technicians).

4. Social and educational-technological environment (teachers, students, leaders and students, as well as the content, direction, unity of purpose, etc. of student interactions).

5. Consistent, continuous and systematic organization of organizational and educational-practical activities.

Future vocational education teachers have a special role in the effective organization of the process of professional formation, as well as educational tools.

The interrelationships between engineering and pedagogical activities contribute to the decisionmaking of the technological approach. Technology is a set of methods that serve to change raw materials, materials, semi-finished products, their processing, as well as their condition, shape and properties.

Simple production technologies have existed since ancient times and have found expression in the content of pedagogical activity. Since technological knowledge, skills and abilities are not transmitted to the younger generation in a biogenetic way, man has mastered it only in the process of necessary training.

By the nature of human activity, pedagogical activity has been its structural basis, as well as an important element of the technological system. Given the genetic interdependence of pedagogical and production activities, the following opinion can be expressed: pedagogical technology in the process of its development has never been separated from production technology (in turn, production technology is pedagogical technology). The level of development of production in all periods was determined by the level of skill of the worker, which in turn depended on his education.

The interrelationship between the disciplines of the pedagogical category and the general engineering disciplines is due to the interpretation of special production technology in the form of art, skill and ingenuity. This idea is still in use at these days.

The transition of secondary special vocational education institutions to the regional level will increase the prestige of the specialties involved in the regions, improve the quality of vocational education, attract employers to cooperate with vocational education institutions, order the training of specialists required in the region.

In summary, the modernization of the vocational education system is associated with the transition to innovative development of the country, the need to strengthen the position of the Uzbek education system in the world market of educational services, the search for new approaches to improving the quality of training in vocational education.

The transition to an information society, which places high demands on the intellectual potential of future professionals in higher education, is aimed at changing the technology of the education system, its technologies and teaching methods, in particular, an active approach to 
solving educational problems.

\section{Conclusion}

The development of students' learning competencies in the educational process allows them to form professional competencies aimed not only at acquiring specific knowledge and skills in the field of engineering and technology, but also the ability to apply them in practice.

In addition, students increase their technical literacy based on the formation of professional competencies, use the ability to perform exercises and practical tasks, organize scientific work with students, use information technology and the ability to independently develop the content of curricula of secondary special vocational education institutions.

Competency (especially professional competency) is formed on the basis of pedagogical and methodological approaches.

Many educators reveal the specifics of vocational education in the restoration of professional pedagogical competence and develop new approaches to teaching, modeling various aspects of pedagogical activity and personality. In our opinion, this will significantly change the content of the professional competence of future vocational education teachers and will be in line with the requirements of society, the social environment and a specific area of professional and pedagogical activity. The following are given as suggestions:

1. The formation of professional competencies in the process of vocational training should be carried out not only with traditions, but also with the introduction of new educational technologies, using innovative forms, methods and tools that ensure the effective implementation of new activities.

2. Improving the management of vocational education - the transfer of management and control of vocational education institutions to higher education institutions. Strengthening cooperation with higher education institutions.

3. Improving the quality of vocational education - the involvement of leading professors and teachers of higher education institutions, the organization of master classes with their participation, the exchange of teachers in the analysis of the lessons, work on overcoming shortcomings through mutual exchange of views.

4. Relying on foreign experience in the development and reform of the education system - for example, the «dual system» in German vocational education (i.e., the system of cooperation with industry) carried out in areas related to agriculture. We are far from convinced that this is exactly what needs to be done, but it is inevitable that the educational process will be effective if the link between theory and practice is systematically established.

5. Improving the content of vocational training of future professionals through the integration of education, science and industry - to improve the professional training of future professionals, it is necessary to strengthen cooperation and increase the responsibility of higher education, vocational training and production organizations.

\section{ReFERENCES}

1. Drapeau Patti. Sparking student creativity (practical ways to promote innovative thinking and problem soving). - Alexandria - Virginia, USA: ASCD, 2014. - p. 4.

2. Зеер Э.Ф., Шахматова Н. Личностью 
CURRENT RESEARCH JOURNAL OF PEDAGOGICS 2(10): 233-240

October 2021 DOI: https://doi.org/10.37547/pedagogics-crjp-02-10-42

ISSN 2767-3278

(C)2021 Master Journals

Crossref doi) 81 Google

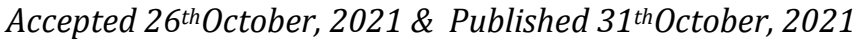

ориентированные технологии

пофессионального

развития

специалиста. - Екатеринбург, 1999. С.60.

3. Муслимов Н.А., Усмонбоева М.Х., Сайфуров Д.М., Тўраев А.Б. Инновацион таълим технологиялари - Т.: “Сано стандарт” нашриёти, 2015. - 81-б.

4. Муслимов Н. ва бошқалар. Касб таълими ўқитувчиларининг касбий компетентлигини шакллантириш технологияси. - Тошкент: «Фан ва технологиялар», 2013. 8 б.

5. Oxtoby W. David, "The Place of the Arts." Liberal Education 98 (2012): 26-41.

6. Очилов М. Янги педагогик технологиялар. Қарши.: Насаф, 2000. 79 б.

7. Рўзиева Д., Усмонбоева М., Холиқова 3. Интерфаол методлар: мохияти ва қўлланилиши / Мет.қўлл. - Т.: Низомий номли ДТПУ, 2013. - 115 б.

8. Рахимов 3.Т. Педагогик компетентлик таълим жараёни ривожланишининг мухим омили сифатида. "Замонавий таълим” илмий-амалий оммабоп журнал - 2019 й. № 7(80). 4-б.

9. Сорокина, Т.М. Развитие учебнопрофессиональной деятельности $\mathrm{y}$ студентов педагогического вуза: Монография / Н.A. Хомова, Т.М. Сорокина. - Н. Новгород: НИУ РАНХиГС, 2013. - 128 c.

10. Ходжабоев А.Р. Учебно-методический комплекс подготовки трудового обучения - Т.: Ўқитувчи, 1989. - 91 с.

11. Хуторской А.В. Ключевые компетенции как компонент личностноориентированной парадигмы образования // Ученик в обновляющейся школе: сб. науч. тр. / под ред. Ю.И. Дика, А.В. Хуторского. - М.: ИОСО РАО, 2002. - 488 с.

12. Хуторской А. В. Компетентность как дидактическое понятие: содержание, структура и модели конструирования / А. В. Хуторской, Л. Н. Хуторская // Проектирование и организация самостоятельной работы студентов в контексте компетентностного подхода: Межвузовский сб. науч. тр. / Под ред. А. А.Орлова. - Тула : Изд-во Тул. гос. пед. ун-та им. Л.Н. Толстого, 2008. - Вып. 1. C.117-137. 